\title{
Physical quality of a Cerrado-biome soil cultivated with three management strategies in forest planted with rubber tree (Hevea brasiliensis)
}

\author{
Yuri Luiz Augusto dos Santos'*, Adriana Aparecida Ribon', Clarice Backes', Alessandro José Marques \\ Santos', Larissa Gabriela Marinho da Silva², Amanda Romeiro Alves ${ }^{3}$, Leonardo Rodrigues Barros ${ }^{2}$, Vladia \\ Correchel $^{2}$, Samara Santos Viana ${ }^{4}$, Nara Rúbia de Morais Arantes ${ }^{2}$
}

\author{
'Universidade Estadual de Goiás, São Luis de Montes Belos - Brazil \\ ${ }^{2}$ Universidade Federal de Goiás, Goiânia - Brazil \\ ${ }^{3}$ Universidade Federal de Santa Maria, Santa Maria - Brazil \\ ${ }^{4}$ Instituto Federal Goiano, Rio Verde - Brazil
}

*Corresponding author: ylas89@gmail.com

\begin{abstract}
The rubber tree is a species native to the Amazon biome of great economic importance. Analyzing the soil physical attributes allows for quantifying the impact of different management practices on the soil properties and the yield of rubber plantations. The present experiment was developed on Red-Latosol soil cultivated with rubber tree (Hevea brasiliensis) since 2013. The experiment was set up as a factorial (2x3) design with two rubber-tree clones (PB 312 and RRIM 600) and three management strategies (organomineral fertilizer - poultry litter; mowing followed by mineral fertilizer application; green manure - pigeonpea [Cajanus cajan], as a cover crop) applied annually, with five replicates. Treatments were applied annually but the soil samples were collected at two times: firstly in 2015 (T1) and subsequently on 2016 (T2). Results revealed a reduction of microporosity, macroporosity, and total porosity and an increase in soil density with depth. However, no significant difference was detected across the management strategies for any of the evaluated traits. The different management strategies did not significantly influence the rubber-tree trunk circumference, suggesting a need for further evaluations throughout the entire development of individuals so that the response of this species can be quantified.
\end{abstract}

Keywords: pedology, organomineral, green manure, rubber cultivation.

\section{Introduction}

Hevea brasiliensis (Willd. ex A. Juss.) Müll. Arg., popularly known as rubber tree, is a forest species native to the Amazon of great social, environmental, and economic importance. Its economic relevance stems from the production of latex, whose peculiar features ensure a resistant and adaptable natural rubber largely used in the manufacture of tires. Satisfactory yields can be obtained by choosing good genetic material if coupled with adequate soil preparation operations and management, besides efficient fertilization. As stated by Ribon et al. (2014), favorable soil physical conditions are essential for good yields in rubber cultivation. An indicator that allows for determining the production response to different management strategies is the analysis of soil physical attributes, as they actively collaborate with several processes related to the development and establishment of forest crops.

The soil physical attributes (e.g. alterations in aggregate stability and penetration resistance) are commonly evaluated to examine the relationship between edaphic conditions, soil management, and yield. Heid et al. (2009) stressed that aggregate formation influences the soil aeration, root development, nutrient supply, resistance, and water storage. One of the physical indicators of management effects on plant productivity is the soil penetration resistance, which enables the diagnosis and evaluation of soil compaction. This indicator provides data on the physical resistance that acts upon the root system of crops, which is influenced by the soil moisture, density, and porosity (Mazurana et al. 2013, Vogel et al. 2017). Aggregate formation is related to the organic matter, which works as a cementing agent. It maintains the stability of aggregates near that seen in natural conditions, and its presence indicates the activity of microbial biomass and enzymes that are sensitive to alterations in soil quality resulting from changes in land use and management practices (Llanillo et al. 2006, Cardoso et al. 2009). Management systems directly interfere with the soil properties and consequently with the yield of crops. An appropriate strategy is the use of organomineral fertilizers, which are employed in the correction of soil acidity and provide nutrients through gradual solubilization, in addition to possibly improving the soil physical properties (Kiehl 2008). Ferreira et al. (2012) declared that green manure plays an important role in the physical, chemical, and biological properties of soil and its conservation by improving its texture and structure, decreasing compaction. It also contributes with carbon and nitrogen, in addition to increasing the faunal diversity. 
In view of the above-mentioned considerations and seeking a better understanding of the interrelationship between factors inherent to the soil and the development of the rubber tree in the soil conditions of the Cerrado biome the present study was developed to characterize the physical quality of soil on the basis of aggregate stability, density, total porosity, macroporosity, penetration resistance, and organic matter contents achieved with three management strategies. Additionally, we aimed to obtain data on the circumference of rubber trees planted on Red-Latosol soil in the cerrado biome.

\section{Results and Discussion}

\section{Analysis of soil physical attributes}

In the area planted with clone PB 312, a significant difference was detected between the times for the amount of aggregates from the $0-0.10 \mathrm{~m}$ layer retained on the $2-\mathrm{mm}$ sieve. At time 1 , there was a larger amount of aggregates in the three management systems for rubber-tree clone PB 312 cultivated in a Red Latosol (Table 1). For the 1-, 0.5-, 0.25-, and $0.105-\mathrm{mm}$ sieves, there was no significant difference between the times. However, a significant difference was observed across management strategies and sieves at the depth of $0.10-0.20 \mathrm{~m}$.

At time 2, for the $0-0.10 \mathrm{~m}$ depth, clone RRIM 600 had more aggregates retained on the $2-\mathrm{mm}$ sieve in all treatments, despite the lack of significant differences. For the 1-, 0.5-, $0.25-$, and $0.105-\mathrm{mm}$ sieves, there was no significant difference between the times or management strategies at both depths analyzed.

All treatments resulted in a higher quantity of aggregates retained on the 2-mm sieve. This phenomenon is common in Latosol classes, since these soils have elevated structural stability provided by the action of aluminum and iron oxides and by the organic matter.

Sandalowski (2013) studied a topossequence by evaluating aggregate stability in three trenches and observed that the highest aggregate stability index was found in the surface volume and on the sieves with larger openings, which may be related to the soil organic matter content (SOM). Our results corroborate those findings, since the SOM found in the present experiment were relatively high, indicating an increase in organic matter content as a result of the treatments.

Salton et al. (2008) emphasized the importance of management strategies in favoring soil aggregation, which will allow the soil to have its structure preserved as closely as possible to its original state when subjected to external forces such as pressures exerted by mechanical operations, in addition to decreased particle losses due to erosion.

The different management strategies did not provide significant statistical differences in soil penetration resistance for either rubber-tree clone evaluated (Fig 1 and 2).

Addressing the soil penetration resistance, Blainski et al. (2008) considered 2.5 MPa a critical level for crop development in clayey soils. By following this criterion, all treatments in the present experiment showed PR values above the limit considered critical for the root development of the crop. The organic matter contents in the soil cultivated with clone PB 312 were not significantly influenced by the management systems. The same was true for the organic matter content of clone RRIM 600 (Fig 3). Despite the lack of significant differences across the treatments, the SOM contents were above $3 \%$, which is considered a high value for this medium-texture soil. Additionally, the green-manure and organomineral treatments also provided higher SOM contents than the treatment involving mowing, which indicates the possibility of obtaining better results over the years. There was no significant interaction effect between the factors (Clone $x$ Fertilizer $\times$ Layers) or between their combinations for the 'macroporosity' attribute (Table 2). Centurion et al. (2004) studied different management systems (mowing, harrowing, green manure) in the inter-row spaces of rubber-tree clones PB 235 and PB RRIM 701 and also did not find differences between the management systems for macroporosity. The authors reported differences only between layers, with values increasing with depth.

In the current study, however, macroporosity decreased with depth regardless of the rubber-tree clone and management system tested, agreeing with the results published by Andreola et al. (2000).

Considering a critical aeration threshold of $0.10 \mathrm{~m}^{3} \mathrm{~m}^{-3}$ (Ferreira 2010) and that lower values can restrict root growth, compromising the plant development, all management systems and layers evaluated here showed macroporosity values below this critical limit.

Macroporosity values less than ideal were also observed by Ribon et al. (2002), who evaluated a management strategy including mowing in the inter-row spaces of rubber tree planted on Red-Latosol soil. However, those authors found adequate values in the treatments using green manure with tropical kudzu and harrowing.

Microporosity was not influenced by the evaluated management systems and clones, with no significant differences obtained across treatments. Centurion et al. (2004) also reported a lack of significant differences for microporosity in response to different management strategies applied to the rubber-tree inter-row space, although lower values were seen in the mowing treatment. Micropores are important for the storage and retention of water in the soil (Ferreira 2010). In this way, alongside the macropores, they are essential components that provide conditions for plant growth and development.

Total porosity was also not significantly influenced by management systems or layers, in clone PB 312. However, clone RRIM 600 showed significant differences across the layers for total porosity, which decreased with depth (Table 3).

Mean total porosity was close to $0.43 \mathrm{~m}^{3} \mathrm{~m}^{-3}$. For clone RRIM 600, in the 0-0.10 m layer, this variable averaged 0.45 $\mathrm{m}^{3} \mathrm{~m}^{-3}$. No differences were found across the management systems evaluated in this study, irrespective of the clone. Centurion et al. (2004) observed that harrowing performed in the inter-row space of rubber tree increased total porosity in the soil surface layer.

Souza and Alves (2003) observed similar results for total porosity in an area cultivated with rubber tree $\left(0.44 \mathrm{~m}^{3} \mathrm{~m}^{-3}\right)$. The management involving rubber tree provided lower total porosity values than that obtained in areas with cerrado 
Table 1. Mean values for aggregates retained on the 2-, 1-, 0.5-, 0.25-, and 0.105-mm sieves for the 0-0.10 m depth of a Red-Latosol soil cultivated with rubber tree (clone PB 312).

\begin{tabular}{|c|c|c|c|}
\hline \multicolumn{4}{|c|}{ 2-mm sieve } \\
\hline Time & Organomineral & Mowing + Mineral & Green manure \\
\hline T1 & $7.86 \mathrm{Aa}$ & $8.25 \mathrm{Aa}$ & 8.09Aa \\
\hline $\mathrm{T} 2$ & $7.08 \mathrm{Ba}$ & 7.15Ba & 7.34Ba \\
\hline \multicolumn{4}{|c|}{ 1-mm sieve } \\
\hline Time & Organomineral & Mowing + Mineral & Green manure \\
\hline T1 & $0.11 \mathrm{Aa}$ & $0.11 \mathrm{Ba}$ & $0.13 \mathrm{Aa}$ \\
\hline $\mathrm{T} 2$ & $0.14 \mathrm{Ab}$ & 2.78Aa & $0.08 \mathrm{Ab}$ \\
\hline \multicolumn{4}{|c|}{$0.5-\mathrm{mm}$ sieve } \\
\hline Time & Organomineral & Mowing + Mineral & Green manure \\
\hline T1 & $0.14 \mathrm{Ab}$ & $0.72 \mathrm{Aa}$ & $0.15 \mathrm{Ab}$ \\
\hline $\mathrm{T} 2$ & $0.18 \mathrm{Aa}$ & $0.12 \mathrm{Ba}$ & 0.09Aa \\
\hline \multicolumn{4}{|c|}{$0.25-\mathrm{mm}$ sieve } \\
\hline Time & Organomineral & Mineral & Green manure \\
\hline T1 & $0.15 \mathrm{Aa}$ & $0.45 \mathrm{Aa}$ & $0.23 \mathrm{Aa}$ \\
\hline $\mathrm{T} 2$ & $0.20 \mathrm{Aa}$ & $0.17 \mathrm{Aa}$ & $0.15 \mathrm{Aa}$ \\
\hline \multicolumn{4}{|c|}{$0.105-\mathrm{mm}$ sieve } \\
\hline Time & Organomineral & Mowing + Mineral & Green manure \\
\hline T1 & $0.13 \mathrm{Aa}$ & $0.40 A a$ & $0.15 \mathrm{Aa}$ \\
\hline $\mathrm{T} 2$ & $0.28 \mathrm{Aa}$ & $0.20 \mathrm{Aa}$ & $0.18 \mathrm{Aa}$ \\
\hline
\end{tabular}

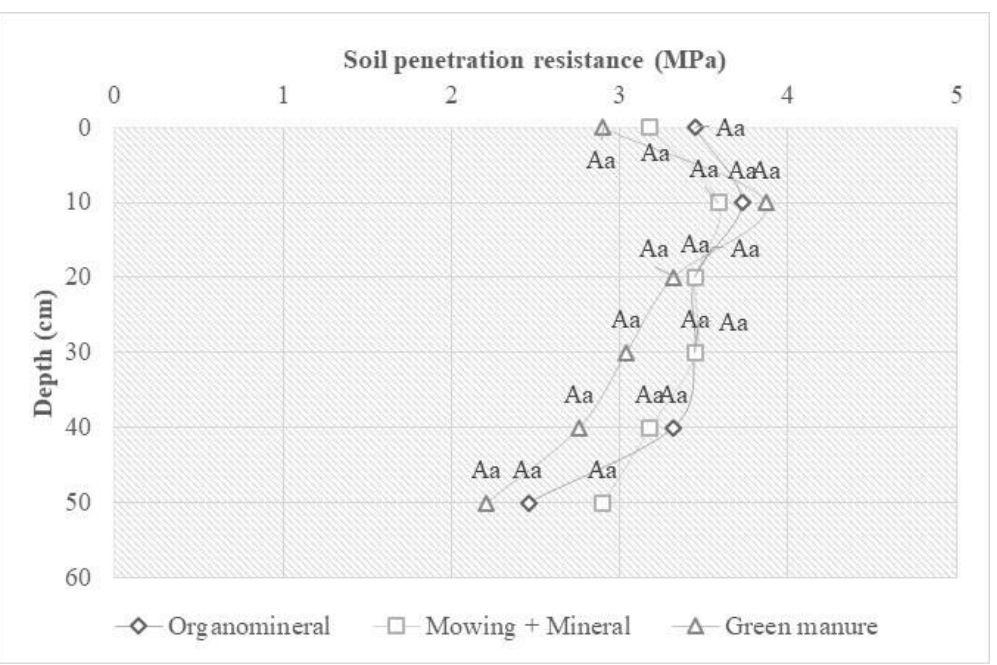

Fig 1. Curve of soil penetration resistance for clone PB312.

Table 2. Mean macroporosity (m3 m-3) of Red-Latosol soil, obtained with different fertilization strategies applied to a rubber-tree crop.

\begin{tabular}{|c|c|c|c|c|}
\hline \multirow{2}{*}{$\begin{array}{l}\text { Layer } \\
\text { (m) }\end{array}$} & \multicolumn{4}{|c|}{ Management strategy } \\
\hline & Organomineral & Green manure & Mowing + mineral & \\
\hline \multicolumn{4}{|c|}{ Clone PB 312} & Mean \\
\hline $0-0.10$ & $0.08 \mathrm{Aa}$ & $0.08 \mathrm{Aa}$ & $0.08 \mathrm{Aa}$ & 0.08 a \\
\hline $0.10-0.20$ & $0.06 \mathrm{Aa}$ & $0.06 \mathrm{Aa}$ & $0.08 \mathrm{Aa}$ & $0.07 \mathrm{ab}$ \\
\hline $0.20-0.30$ & $0.06 \mathrm{Aa}$ & $0.07 \mathrm{Aa}$ & $0.06 \mathrm{Aa}$ & $0.06 \mathrm{~b}$ \\
\hline $0.30-0.40$ & $0.06 \mathrm{Aa}$ & $0.07 \mathrm{Aa}$ & $0.05 \mathrm{Aa}$ & $0.06 \mathrm{~b}$ \\
\hline \multicolumn{4}{|c|}{ Clone RRIM 600} & Mean \\
\hline $0-0.10$ & $0.08 \mathrm{Aa}$ & $0.09 \mathrm{Aa}$ & $0.09 \mathrm{Aa}$ & 0.08 a \\
\hline $0.10-0.20$ & $0.06 \mathrm{Aa}$ & $0.07 \mathrm{Aa}$ & $0.07 \mathrm{Aa}$ & $0.07 \mathrm{~b}$ \\
\hline $0.20-0.30$ & $0.06 \mathrm{Aa}$ & $0.06 \mathrm{Aa}$ & $0.06 \mathrm{Aa}$ & $0.06 \mathrm{~b}$ \\
\hline $0.30-0.40$ & $0.05 \mathrm{Aa}$ & $0.06 \mathrm{Aa}$ & $0.07 \mathrm{Aa}$ & $0.06 \mathrm{~b}$ \\
\hline \multicolumn{2}{|c|}{ Mean (Clone PB 312) } & \multicolumn{3}{|c|}{$0.06 a$} \\
\hline \multicolumn{2}{|c|}{ Mean (Clone RRIM 600) } & \multicolumn{3}{|c|}{$0.07 a$} \\
\hline
\end{tabular}




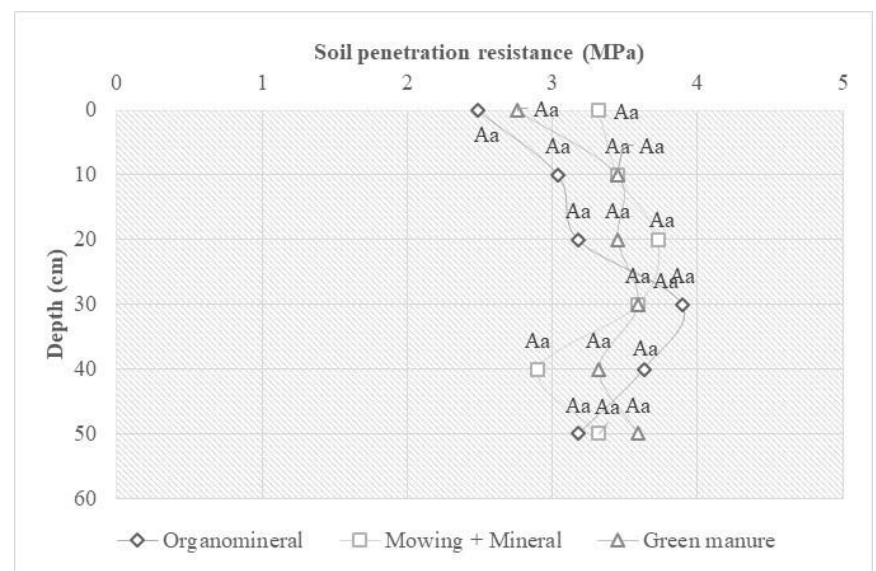

Fig 2. Curve of soil penetration resistance for clone RRIM600.

Table 3. Mean total porosity (m3 m-3) of Red-Latosol soil, obtained with different fertilization strategies applied to a rubber-tree crop.

\begin{tabular}{|c|c|c|c|c|}
\hline \multirow{2}{*}{$\begin{array}{l}\text { Layer } \\
(\mathrm{m})\end{array}$} & \multicolumn{4}{|c|}{ Management strategy } \\
\hline & Organomineral & Green manure & Mowing + mineral & \\
\hline Clone PB 312 & & & & Mean \\
\hline $0-0.10$ & $0.43 \mathrm{Aa}$ & $0.41 \mathrm{Aa}$ & $0.43 \mathrm{Aa}$ & $0.43 a$ \\
\hline $0.10-0.20$ & $0.41 \mathrm{Aa}$ & $0.43 \mathrm{Aa}$ & $0.42 \mathrm{Aa}$ & $0.42 a$ \\
\hline $0.20-0.30$ & $0.42 \mathrm{Aa}$ & $0.42 \mathrm{Aa}$ & $0.41 \mathrm{Aa}$ & $0.42 a$ \\
\hline $0.30-0.40$ & $0.42 \mathrm{Aa}$ & $0.42 \mathrm{Aa}$ & $0.42 \mathrm{Aa}$ & $0.42 a$ \\
\hline Clone RRIM 600 & & & & Mean \\
\hline $0-0.10$ & $0.45 \mathrm{Aa}$ & $0.45 \mathrm{Aa}$ & $0.45 \mathrm{Aa}$ & $0.45 a$ \\
\hline $0.10-0.20$ & $0.42 \mathrm{Ab}$ & $0.43 \mathrm{Aa}$ & $0.42 \mathrm{Aa}$ & $0.43 \mathrm{~b}$ \\
\hline $0.20-0.30$ & $0.42 \mathrm{Ab}$ & $0.43 \mathrm{Aa}$ & $0.42 \mathrm{Aa}$ & $0.42 \mathrm{~b}$ \\
\hline $0.30-0.40$ & $0.42 \mathrm{Ab}$ & $0.42 \mathrm{Aa}$ & $0.42 \mathrm{Aa}$ & $0.42 \mathrm{~b}$ \\
\hline Mean (Clone PB 312) & \multicolumn{4}{|c|}{$0.42 a$} \\
\hline Mean (Clone RRIM 600) & \multicolumn{4}{|c|}{$0.43 a$} \\
\hline
\end{tabular}

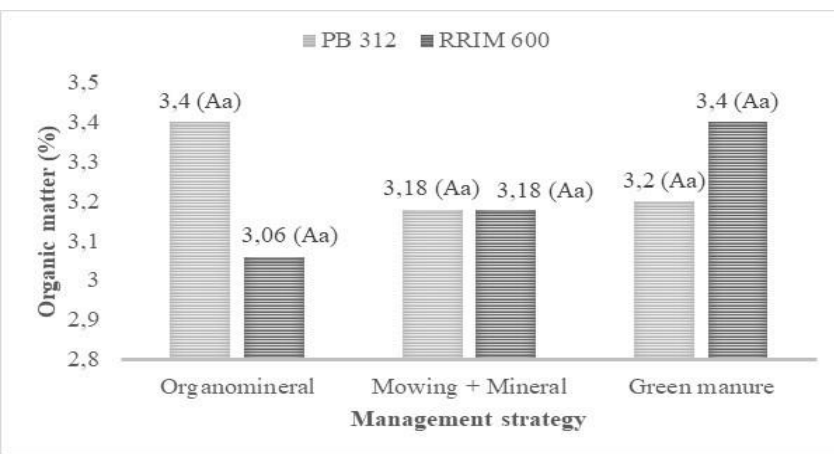

Fig 3. Soil organic matter contents in the three management systems, for clones PB312 and RRIM 600.

Table 4. Mean density (mg m-3) of Red-Latosol, soil obtained with different fertilization strategies applied to the rubber-tree crop.

\begin{tabular}{|c|c|c|c|c|}
\hline \multirow{2}{*}{$\begin{array}{l}\text { Layer } \\
\text { (m) }\end{array}$} & \multicolumn{4}{|c|}{ Management strategy } \\
\hline & Organomineral & Green manure & Mowing + Mineral & \\
\hline Clone PB 312 & & & & Mean \\
\hline $0-0.10$ & $1.14 \mathrm{~A} \quad \mathrm{~b}$ & $1.12 \mathrm{~A} \quad \mathrm{~b}$ & $1.12 \mathrm{~A} \quad \mathrm{~b}$ & $1.13 \mathrm{~b}$ \\
\hline $0.10-0.20$ & $1.18 \mathrm{~A} a b$ & $1.17 \mathrm{~A} a b$ & $1.16 \mathrm{~A} a b$ & $1.17 \mathrm{ab}$ \\
\hline $0.20-0.30$ & $1.22 \mathrm{~A} \mathrm{a}$ & $1.18 \mathrm{~A} \mathrm{a}$ & $1.20 \mathrm{Aab}$ & $1.19 \mathrm{a}$ \\
\hline $0.30-0.40$ & $1.20 \mathrm{~A} a b$ & $1.16 \mathrm{~A} a b$ & $1.21 \mathrm{Aa}$ & $1.20 \mathrm{a}$ \\
\hline Clone RRIM 600 & & & & Mean \\
\hline $0-0.10$ & $1.12 \mathrm{~A} \quad \mathrm{~b}$ & $1.09 \mathrm{~A} \mathrm{~b}$ & $1.11 \mathrm{~A} \quad \mathrm{~b}$ & $1.10 \mathrm{~b}$ \\
\hline $0.10-0.20$ & $1.13 \mathrm{~A} a b$ & $1.12 \mathrm{~A} a b$ & $1.15 \mathrm{~A} a b$ & $1.13 \mathrm{ab}$ \\
\hline $0.20-0.30$ & $1.16 \mathrm{~A} a b$ & $1.14 \mathrm{~A} a b$ & $1.15 \mathrm{~A} a b$ & $1.15 \mathrm{a}$ \\
\hline $0.30-0.40$ & $1.16 \mathrm{~A} a b$ & $1.15 \mathrm{~A} a b$ & $1.15 \mathrm{~A} a b$ & $1.15 \mathrm{a}$ \\
\hline Mean (Clone PB 312) & & $1.17 \mathrm{a}$ & & \\
\hline Mean (Clone RRIM 600) & & $1.13 \mathrm{~b}$ & & \\
\hline
\end{tabular}




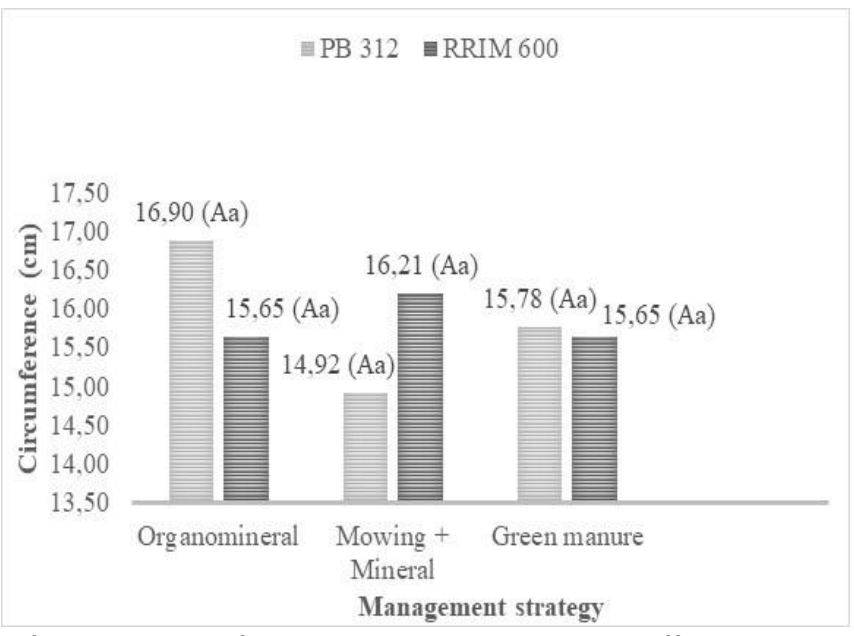

Fig 4. Mean circumference values of the two clones, obtained with different management strategies.

stricto sensu vegetation $\left(0.54 \mathrm{~m}^{3} \mathrm{~m}^{-3}\right)$ and minimum tillage $\left(0.53 \mathrm{~m}^{3} \mathrm{~m}^{-3}\right)$ on a Red Latosol. Portugal et al. (2008) found similar physical attributes (soil density and macro- and microporosity) in a Haplic Cambisol (Ochrept, Umbrept) between management systems in rubber-tree and nativeforest areas. The management strategies (organomineral fertilizer, green manure, and mineral fertilizer) elicited similar responses from soil density, which rose with depth. Differences were also detected between the studied clones for this variable, with PB 312 showing higher values than RRIM 600; i.e., in the planting area of the latter clone, irrespective of the analyzed layer and strategy employed, the soil density was lower than that observed in the area planted with PB 312 (Table 4). Vieira et al. (2010) investigated the spatial variability of the physical attributes of a Red-Yellow Argisol (Ultisol, Alfisol) under conventional planting of rubber tree (Clone PB 235) intercropped with leguminous species and observed subsurface compaction (highest soil density at the layers from 0.20 to $0.40 \mathrm{~m}$ ). The authors also highlighted an inversely proportional relationship between the rubber-tree trunk circumference and soil density. Conventional preparation by plowing and harrowing increases the soil density and reduces macroporosity and total porosity in the surface layers (Stone and Silveira 1997, Bertol et al. 2000), as seen in results reported by Vieira et al. (2010).

Soil density values were close to $1.13 \mathrm{mg} \mathrm{m}^{-3}$ in the $0-0.10 \mathrm{~m}$ layer. Ribon et al. (2002) examined different management strategies applied to the inter-row space of rubber tree on two soil types. In Red Latosol, the researchers found that irrespective of the strategy adopted, considering a critical value of $0.10 \mathrm{~m}^{3} \mathrm{~m}^{-3}$, the soil density should be lower than $1.36 \mathrm{~kg} \mathrm{dm}^{-3}$ to allow for minimum aeration conditions.

For the soil conditions evaluated in this study (Red Latosol), all density values corresponded to critical aeration conditions; e.g., the average macroporosity value in the 0 $0.10 \mathrm{~m}$ layer, with a density of $1.13 \mathrm{mg} \mathrm{m}^{-3}$, is $0.08 \mathrm{~m}^{3} \mathrm{~m}^{-3}$. These results indicate the importance of relating indicator attributes in the evaluation of the soil physical quality.

Centurion et al. (2004) observed, in a Red Latosol (Udox, Ustox) cultivated with rubber tree, that soil density values greater than $1.27 \mathrm{~kg} \mathrm{dm}^{-3}$ were detrimental to soil aeration, corresponding to aeration values lower than $0.10 \mathrm{~m}^{3} \mathrm{~m}^{-3}$.

\section{Analysis of rubber-tree circumference in the three management systems}

No statistical difference was observed for the rubber-tree trunk circumferences obtained with the different management strategies or between the clones (Fig 4).

Trunk circumference plays a significant role in the productivity of dry rubber from rubber-tree clones, as it is considered the most important parameter for determining planting maturity and the onset of production (Alem et al. 2015, Conforto et al. 2015). According to Arantes et al. (2013) clone RRIM 600 is more adaptable to different soilclimate conditions. Notwithstanding this feature, no superiority was observed on the average of the circumferences when compared with the other clone evaluated in this experiment.

In numerical terms, clone PB 312, which is still today implemented on an experimental scale, was more responsive to the organomineral treatment, possibly indicating that it is a better alternative for cerrado soils. This finding corroborates Carvalho et al. (2015), who reported that organomineral application was the most suitable treatment for the cultivation of a high-nutrient-demanding tree species.

\section{Materials and Methods}

\section{Plant materials and conditions of the study area}

The study was carried out on a medium-texture soil classified according to EMBRAPA (2013) as a Red Latosol (Udox, Ustox), on Baru Farm, located in Palmeiras de Goiás GO, Brazil (16045'28.3”' S 5004'55.6”'W). The original vegetation in the region is a Cerrado stricto senso (savannahlike), which was suppressed in 1970 for the implementation of Brachiaria. The soil management for the planting of the rubber trees began in 2013, when the area appeared to be under intense degradation and the treatments occurred annually since then.

Before the onset of the experiment, the soil had the following chemical properties, analyzed in the $0-20 \mathrm{~m}$ layer: $\mathrm{pH}\left(\mathrm{CaCl}_{2}\right)$ - 5.6; P - $9 \mathrm{mg} \mathrm{dm}{ }^{-3} ; \mathrm{Mg}-0.8 \mathrm{cmolc} \mathrm{dm}^{-3} ; \mathrm{Ca}-3.3$ cmolc $\mathrm{dm}^{-3} ; \mathrm{K}-105 \mathrm{mg} \mathrm{dm}{ }^{-3}$; and sand, silt, and clay - 310, 350 , and $340 \mathrm{~g} \mathrm{~kg}^{-1}$, respectively. 
Dolomitic lime (79\% RNV and 92\% NV) was applied in the area without incorporation at the rate of $3 \mathrm{t} \mathrm{ha}^{-1}$ in October 2013. Holes were fertilized at the time of planting with $250 \mathrm{~g}$ NPK (11-44-00) + 10\% FTE BR-12 per seedling. After one year, topdressing was performed with $60 \mathrm{~g}$ NPK (20-00-20) per plant. The planting spacing adopted was $6 \times 3.3 \mathrm{~m}$, using clones RRIM 600 and PB-312, which were obtained with the help of the experimental station of the Agronomic Institute of Campinas (IAC).

\section{Treatments (cultivars $x$ management strategies)}

The experiment was set up as a factorial $(2 \times 3)$ design with two rubber-tree clones and three management strategies applied in the inter-row space (organomineral fertilizer poultry litter; mowing followed by mineral fertilizer application; and green manure - pigeonpea [Cajanus cajan (L) Hunth], as the cover crop), applied annually with five replicates. The ten central trees were considered the usable plot, totaling a $198-\mathrm{m}^{2}$ area.

Cultivation practices performed on the rubber-tree inter-row spaces prior to the implementation of the experiment were manual weeding in the planted region, application of the Goal $^{\circ}$ herbicide, desiccation with glyphosate, and mechanical mowing.

\section{Traits measured}

Treatments were applied annually but the soil samples were collected at two times: firstly in December 2015 (T1) and subsequently on December 26, 2016 (T2).

Plants were mowed three times per year, in the rainy period. In this process, the plant material was ground and then applied into the crop inter-row spaces. The legume (pigeonpea) was broadcast at the density of $297 \mathrm{~g} /$ plot. The organomineral fertilizer (poultry litter) was broadcast into the crop inter-row spaces at the rate of $20 \mathrm{~kg} / \mathrm{plot}$, without incorporation, once yearly. All fertilizer applications were based on the nutritional requirements of the rubber-tree crop revealed by the previously mentioned soil chemical analysis performed at the $0-0.20 \mathrm{~m}$ depth.

One hundred and fifty days after each experimental implementation ( $\mathrm{T} 1$ and $\mathrm{T} 2$ ), two undisturbed soil samples per treatment were collected from the 0-10 and 0.10-0.20 m layers using a mattock and a jackknife, totaling 30 samples of each clone. Penetration resistance data were also collected using an impact penetrometer up to the depth of $60 \mathrm{~cm}$.

Samples to determine aggregate stability in water were collected from the $0-0.10$ and $0.10-0.20 \mathrm{~m}$ depths. In the laboratory, they were sieved through 8-mm openings, dried in the shade for $72 \mathrm{~h}$, and analyzed via wet sieving, following the method proposed by Yoder (1936). The average weighted diameter of the water-stable aggregates was calculated by the method described by Kemper and Chepil (1965).

Samples were also harvested from these layers for a chemical analysis to determine the soil organic matter contents, in accordance with Raij et al. (1987). The method of Franzluebbers (2002) was adopted to determine the soil organic $C$ stratification rate. The soil organic $C$ contents quotient was calculated at the same depths as those used for the aggregate samples.
Soil penetration resistance (PR) data were also collected using a IAA/Planalsucar/Stolf impact penetrometer for the depths of $0-0.10,0.10-0.20,0.20-0.40,0.40-0.60 \mathrm{~m}$, in which the number of impacts $\left(\mathrm{dm}^{-1}\right)$ was transformed into dynamic resistance (MPa) by using the equation proposed by Stolf (1991): PR $\left(\mathrm{kgf} \mathrm{cm}^{-2}\right)=5.6+6.89 \mathrm{~N}$ (impacts $\mathrm{dm}^{-1}$ ). To convert PR in $\mathrm{kgf} \mathrm{cm}^{-2}$ into $\mathrm{MPa}$, the obtained result was multiplied by the 0.098 constant.

On the date corresponding to $T 1$, samples with preserved structure were harvested from all plots in the rubber-tree projection area at the depths of $0-0.10,0.10-0.20,0.20-0.30$, 0.30-0.40 $\mathrm{m}$ to determine microporosity (tension table) and soil density (sample ring method), following EMBRAPA (2011). Total porosity was determined based on the saturation volume of the sample, whereas macroporosity was calculated as the difference between total porosity and microporosity, as described by EMBRAPA (2011).

The rubber-tree clones had their development assessed based on the mean circumferences of the trunks measured at $1.30 \mathrm{~m}$ above the soil, in August 2017. In each of the four replicates, for the three management strategies, the circumferences of 30 individuals were measured.

\section{Statistical analysis}

Soil aggregate stability, penetration resistance, density, total porosity, macroporosity, microporosity, and organic matter contents and tree trunk circumference data were subjected to analysis of variance and Tukey's test at the $5 \%$ significance level using R software (R CORE TEAM 2018).

\section{Conclusion}

All clones and management strategies evaluated here showed a reduction of macroporosity and total porosity and an increase in soil density with depth. However, the three management systems did not lead to differences in trunk circumference or in the soil physical properties. This reaffirms the need for continuous assessments throughout the development of trees so that more-accurate results can be obtained for the interaction of management strategies on the soil physical quality and dendrometric data.

\section{Acknowledgements}

This study is partly dissertation to obtain Master's degree in Sustainable Rural Development at the State University of Goiás (UEG). The authors thank the Agronomic Institute of Campinas (IAC) by the genetic material of rubber trees, Organomax Company for providing the organomineral and the Baru farm that provided a study area. The authors wish to acknowledge the Soil Physics Laboratory [Goiás Federal University (Goiânia, Brazil)] for the technological support.

\section{References}

Aguiar ATE, Martins ALM, Gonçalves ECP, Scaloppi Júnior EJS, Branco RBF (2010) Correlações e análise de trilha em clones de seringueira. Rev Ceres. 57(5): 602-607.

Alem HM, Gouvêa LRL, Silva GAP, Oliveira ALB, Gonçalves PS (2015) Avaliação de clones de seringueira para a região noroeste do Estado de São Paulo. Rev Ceres. 62(5): 430437. 
Andreola F, Costa LM, Olzevki N (2000) Influência da cobertura vegetal de inverno e da adubação orgânica e ou mineral sobre as propriedades físicas de uma Terra Roxa Estruturada. Rev Bras Ciênc Solo. 24: 857-865.

Arantes FC, Scaloppi Júnior EJS, Gonçalves PS, Moraes MLT, Gonçalves ECP, Resende MDV (2013) Adaptability and stability in rubber tree progenies under diferente environmental conditions. Pesqui Florest Bras. 33(73): 3744.

Bastos RS, Mendonça ES, Alvarez VH, Corrêa MM, Costa LM (2005) Formação e estabilização de agregados do solo influenciados por ciclos de umedecimento e secagem após adição de compostos orgânicos com diferentes características hidrofóbicas. Rev Bras Ciênc Solo. 29(1): 2131.

Bertol I, Schick J, Massariol JM, Reis EF, Dily L (2000) Propriedades físicas de um Cambissolo Húmico álico afetadas pelo manejo do solo. Cienc Rural. 30: 91-95.

Blainski E, Tormena CA, Fidalski J, Guimarães RML (2008) Quantificação da degradação física do solo por meio da curva de resistência do solo à penetração. Rev Bras Ciênc Solo. 32: 975-983.

Calegari A, Castro Filho C, Tavares Filho J, Ralishc R, Guimarães MF (2006) Melhoria da agregação do solo através do sistema plantio direto. Semina. 27(2): 147-158.

Cardoso EL, Silva MLN, Moreira FMS, Curi N (2009) Atributos biológicos indicadores da qualidade do solo em pastagem cultivada e nativa do Pantanal. Pesq Agropec Bras. 44: 631637.

Centurion JF, Roque CG, Centurion MAPC, Prado RM (2004) Manejo mecânico e cultura de cobertura na entrelinha da seringueira (PB 235 e RRIM 701) e os atributos físicos de um Latossolo Vermelho no Planalto Paulista. Rev Árvore. 28: 7-13.

Conforto EC, Santos JF, Zeuli MR, Andreoli RP (2015) Desenvolvimento inicial de clones IAC de seringueira em São José do Rio Preto, SP. Cienc Rural. 45(7): 1235-1240.

Diniz PFA, Oliveira LEM, Gomes MP, Castro EM, Mesquita AC, Bonome LTS, Silva L (2010) Crescimento, parâmetros biofísicos e aspectos anatômicos de plantas jovens de seringueira inoculadas com fungo micorrízico arbuscular Glomus clarum. Acta Bot Bras. 24(1): 65-72.

EMBRAPA (2011) Manual de Métodos de Análise de Solo. 2 ed. Rio de Janeiro: SNLCS. 225p.

EMBRAPA (2013) Sistema brasileiro de classificação de solos. 3ed. Brasília: EMBRAPA. 353p.

Ferreira MM (2010) Caracterização Física do Solo. In: Lier QJV (ed) Física do solo. Sociedade Brasileira de Ciência do Solo. 1-24p.

Ferreira LE, Souza EP, Chaves AF (2012) Revisão de Literatura: Adubação verde e seu efeito sobre os atributos do solo. Rev Verde. 7(1): 33-38.

Franzluebbers AJ (2002) Soil organic matter stratification ratio as an indicador of soil quality. Soil Tillage Res. 66: 95106.

Heid DM, Vitorino ACT, Tirloni C, Hoffmann NTK (2009) Frações orgânicas e estabilidade dos agregados de um LATOSSOLO vermelho distroférrico sob diferentes usos. Rev Ciênc Agrár. 51: 143-160.

Kiehl EJ (2008) Fertilizantes Organominerais. Piracicaba: Editora Degaspari. 160p.

Kemper WD, Chepil WS (1965) Size distribution of aggregates. In: Black CA (ed) Methods of soil analysis. Part
1. Agronomy n.9, American Society of Agronomy, Inc., Publishes, Madison, Wisconsin.

Llanillo RF, Richart A, Tavares Filho J, Guimarães MF, Ferreira RRM (2006) Evolução de propriedades físicas do solo em função dos sistemas de manejo em culturas anuais. Semina. 27(2): 205-220.

Mazurana M, Fink JR, Silveira VH, Levien R, Zulpo L, Brezolin D (2013) Propriedades físicas do solo e crescimento de raízes de milho em um Argissolo Vermelho sob tráfego controlado de máquinas. Rev Bras Ciênc Solo. 37(5): 11851195.

Portugal AF, Costa ODV, Costa LM, Santos BCM (2008) Atributos químicos e físicos de um Cambissolo Háplico tb distrófico sob diferentes usos na zona da mata mineira. Rev Bras Ciênc Solo. 32: 249-258.

Raiji BV, Quaggio JA, Cantarella H, Ferreira M, Lopes AS, Bataglia OC (1987) Análise química do solo para fins de fertilidade. Fundação Cargill. 170 p.

Raiji BV, Quaggio JA (1983) Métodos de análise de solo para fins de fertilidade. IAC. Boletim Técnico, 81. Instituto Agronômico. 31p.

Ribon AA, Centurio JF, Centurio MAPC, Carvalho Filho A (2002) Propriedades físicas de Latossolo e Argissolo em função de práticas de manejo aplicadas na entrelinha da cultura da seringueira (Hevea brasiliensis). Rev Bras Ciênc Solo. 26: 781-787.

Ribon AA, Centurion JF, Centurion MAPC, Fernandes KL, Hermógenes VT (2014) Alterações na estabilidade de agregados de LATOSSOLO e ARGISSOLO em função do manejo, na entrelinha da seringueira (Hevea brasiliensis). Rev Árvore. 38(6): 1065-1071.

Roque CG, Centurion JF, Pereira GT, Beutler NA, Freddi OS, Andrioli I (2006) Mapeamento da produtividade e perímetro do tronco de clones de seringueira em argissolo vermelho amarelo. Sci For. 70: 59-66.

Souza ZM, Alves MC (2003) Propriedades físicas e teor de matéria orgânica em um Latossolo Vermelho de cerrado sob diferentes usos e manejos. Acta Sci Agron. 25(1): 2734.

Stone LF, Silveira PM (1999) Efeitos do sistema de preparo na compactação do solo, disponibilidade hídrica e comportamento do feijoeiro. Pesqui Agropecu Bras. 34: 83- 91.

Sandalowski FC (2013) Análise da estabilidade de agregados do solo na conformação de vertente em uma topossequência no munícipio de Gaurama - RS. 85p. Dissertation (Masters in Geography and Geosciences) University of Santa Maria, Santa Maria - RS.

Yoder RE (1936) A direct method of agregate analyses soil and a study of the physical nature of erosin losses. Agron J. 28 (3): 337-351.

Vieira SR, Brancalião SR, Greco CR, Martins ALM (2010) Variabilidade espacial de atributos físicos de um Argissolo Vermelho-Amarelo cultivado com leguminosas consorciada com a seringueira. Bragantia. 69(2): 423-432.

Vogel GF, Martinkosk L, Grillo JF, Michalovicz L, Fey R (2017) Avaliação dos penetrômetros de impacto e eletrônico na determinação da resistência mecânica a penetração do solo. Sci Agrar. 18(3): 30-36. 